\title{
Economic Growth Projection for European Union by 2030
}

EIS 13/2019

\author{
Economic Growth \\ Projection for \\ European Union by \\ 2030
}

Submitted 08/2019

Accepted for publication 10/2019

\section{Paweł Młodkowski}

School of International Liberal Arts, Miyazaki International College, Japan
$\Gamma$ Crossef http://dx.doi.org/10.5755/j01.eis.0.13.23709
The paper contributes to a discussion on developments in output for the EU-27 group over the next 11 years, up to year 2030. It departs from a discussion on arguments of the production function, with focus on sudden changes to population in Europe, its growth rate and composition. A brief study of population-decreasing events in the European historical perspective may represent an inspiring part. Reasons for inconsistency in estimated parameters of production function for European countries seems to be well-explained this way.

The projection for the next 11 years, up to 2030 has employed the production function framework. Parameters have been estimated on the period $2004-2016$ that matches most closely conditions that one may expect over the projection horizon.

Feeding the estimated production function for the 2018-2030 forecast has employed projected population by Eurostat, while private capital investment has been generated by an ARIMA model. Projection is offered in two forms: (1) aggregated real output for the whole EU, and (2) the same category for each of the EU-27 countries.

KEYWORDS: EU, economic growth, real output projection, common EU policy, production function, population.

The contribution of this paper is in a form of the real output projections for the EU countries. Assessment of future growth path provides valuable insight for policymakers, and government agencies. Value for economic research is in evaluating efficiency and (later) accuracy of methods tested during the empirical exercise. This paper is an attempt to deliver outcomes that are valuable for both, policymakers, and researchers. Economic policy questions addressed here are EU-wide, and not country-specific.

Due to the gist of the framework used in formulating projections, two factors received attention. Namely, these are population (labor force) developments, and private capital spending that are taken into consideration. Such choice has been motivated by the current situation. European Union faces discussions and decisions on managing refugees, addressing the problem of aging EU's societies, and handling migration in the most productive manner. Estimated production functions for each of EU-27 countries show which of them are characterized with the highest, and positive, economies of scale. This information may be used for allocating migrants in the most productive manner, for the sake of maximizing benefits for the EU.

Most recent studies focused on economic growth in the EU showed interesting behavior of production function parameters at the country-level. As reported in Młodkowski (2019), one can distinguish at least two, if not three, groups of European countries that have grown in a very different manner since 2004. The reasons are possibly associated with post-accession adjustments and common EU policies. Flows of goods, capital, and labor within the Common Market have
Abstract

\section{Introduction}

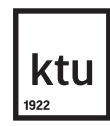

European Integration Studies No. 13 / 2019, pp. 61 - 69 doi.org/10.5755/j01.eis.0.13.23709 
Table 1

Summary review of conflicts in Europe, since the 19th century.

Table 2

Diseases in Europe with more than 10000 lives lost, since 1800 .

Table 3

Genocide in Europe in $20^{\text {th }}$ century. brought about permanent changes to transformation mechanism. The way factors of production are combined for the sake of the real output seem to be significantly modified, but mostly for the New Member States. The group that have joined the EU in 2004 is characterized with negative coefficients for labor in production function. This, has a straight, but erroneous interpretation. A negative influence on real GDP executed by increased endowment of labor (Mtodkowski 2019) is simply a consequence of socio-economic transformation. Such an anomaly is a consequence of substantial alterations to national population features (qualitative and quantitative) in these countries. It should be noted that instability of European population has been quite persistent in the past.

These are social scientists working on 'peace' (Brecke 2012), and historians in economic history (Le May 2016) that deliver estimates of population developments. Reviewing difficult European history one can spot countless examples of negative and sudden changes to composition of un-

\begin{tabular}{l|c|c}
\multicolumn{1}{c|}{ Century } & Number of conflicts & Lives lost (underestimated) \\
\hline $19^{\text {th }}$ century & 152 & 9262554 \\
\hline 20th century & 130 & 76011621 \\
\hline Total & 282 & 85274175 \\
\hline
\end{tabular}

Source: Author, based on Brecke (2012).

\begin{tabular}{|c|c|c|c}
\hline \multicolumn{1}{|c|}{ Period } & Disease Name & \multicolumn{2}{c}{ Region affected } \\
\hline 1813 & plague & Romania & 70000 \\
\hline $1816-1819$ & typhus & Ireland & 65000 \\
\hline $1829-1851$ & cholera & Europe & 73279 \\
\hline $1852-1860$ & cholera & Russia & 1000000 \\
\hline 1857 & yellow fever & Portugal & 40000 \\
\hline $1866-1867$ & cholera & Russia, Germany & 225000 \\
\hline $1870-1871$ & smallpox & Germany & 75712 \\
\hline $1899-1923$ & cholera & Europe & 800000 \\
\hline $1918-1922$ & typhus & Russia & 3000000 \\
\hline
\end{tabular}

Source: Author, based on Ackerknecht (1965), Gregg (1985), Patterson (1993), Paneth et al. (1998), Porter (2001), Hays (2005), Fusco (2007), LeMay (2016), Ross (2018), and UCLA School of Public Health (2018).

\begin{tabular}{|c|c|c|}
\hline Genocide name & Region affected & Body count \\
\hline $\begin{array}{l}\text { Holodomor (Ukrainian genocide which is part of } \\
\text { greater Soviet famine of 1932-33) }\end{array}$ & $\begin{array}{l}\text { Ukrainian Soviet Socialist } \\
\text { Republic }\end{array}$ & 7500000 \\
\hline Porajmos (Romani genocide) & Nazi controlled Europe & 500000 \\
\hline Polish Operation of the NKVD (Polish genocide) & Soviet Union & 111091 \\
\hline Latvian Operation of the NKVD (Lativian genocide) & Soviet Union & 16573 \\
\hline The Holocaust / Nazi genocides and war crimes & $\begin{array}{l}\text { Nazi-Germany controlled } \\
\text { Europe }\end{array}$ & $17000000^{*}$ \\
\hline Genocide by the Ustaše (Serbian genocide) & Independent State of Croatia & 600000 \\
\hline Bosnian genocide & Bosnia and Herzegovina & 301107 \\
\hline
\end{tabular}

* Most of non-Jewish Holocaust victims were Polish Catholics.

Source: Author, based on Rosefielde (1983), Niewyk (2000), Goldman (2011), Calic (2012), Holocaust Encyclopedia. 
derlying societies. These were diseases and plagues (Table 1), wars, revolutions, and uprisings (Table 2), supplemented by cases of genocide (Table 3 ) conducted in a variety of ways, and with diverse motivation.

With all these fact on and features of European economic system in mind, there is a serious doubt that there is a projection method that could handle forecasting for the EU effectively. On the top of instability-related issues reported above, there is still one more factor that contributed to increased difficulty in capturing transformation mechanism of inputs into output, using historical records. This has been the very process of economic integration within the Common Marketthat resulted in sudden, deep, and permanent changes to the composition of the working population in the EU, at country-level. These changes are symmetric, but not in the OCA meaning of „symmetry-asymmetry". There are two groups of countries within the EU that experience this very special symmetric change. New Member States have witnessed substantial (in absolute and relative terms) outflow of the most productive workers to the richest EU members. Rich EU states have welcome well-educated, and highly productive labor available at lower microeconomic, and macroeconomic cost. Symmetrically, New Member States have suffered from accumulated shortage of skilled, and educated workers, and from growing cost-of-labor. When casting this situation in labor market setup (Figure 1) the postulated symmetry in the two groups of EU states becomes evident.

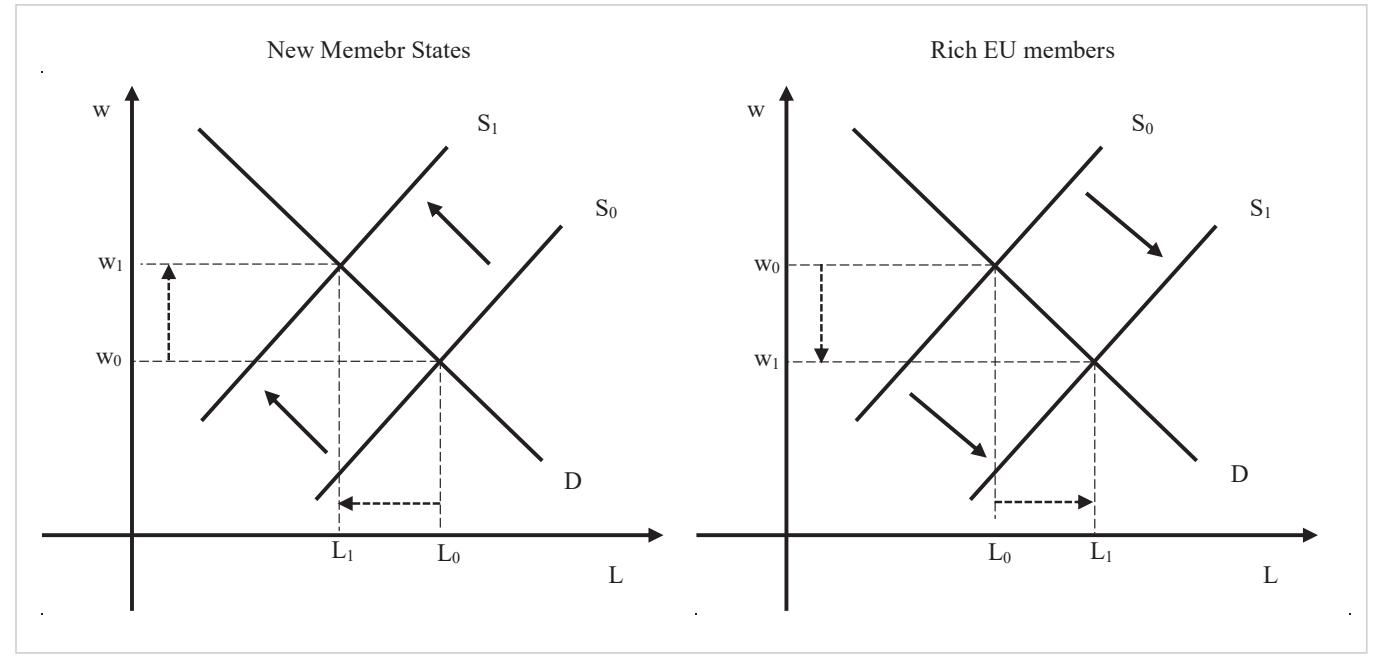

Withessing such changes to the working population in the EU one could expect a very similar symmetric effects in real output in both groups. However, there have been other factors in play that have led to an interesting anomaly reported in the empirical part of this paper.

There is plenty of methods available for handling the task at hand. Among endogenous growth models one can find several competing approaches. This paper employs production function as a framework traditionally used in political economy, since the original idea by Wicksell. Production function can serve in a wide variety of economic studies. The underlying concept is useful not only in political economy, but also in economic policy studies, industrial policy considerations, operational management, and even in economic system analysis, when ethics are involved. On the top of that production function framework allows for forecasting and simulations by capturing the very nature of transformation process that results in the real output. The idea to describe production process as the transformation of labor and capital came from Wicksell. This was a common way of analyzing economic
Figure 1

Symmetric supply shock: labor market in the EU: New Memeber States versus rich EU members (Author).

Methodology 
relations already at the time of Marx. The main proponents of production function framework were Cobb and Douglas (Douglas 1976). Its popularity peaked in 1950s and 1960s, when it served in studying contribution of labor and capital to the real output. As such, production function was employed in economic policy analysis, supporting decision makers in the private sector, and at government.

Interpretation of structural parameters of production function seem most useful in the current situation in Europe. Unprecedented socio-economic issues are to be addressed by all EU countries jointly. It calls for studies that have a potential to provide feedback useful in managing challenges in the most productive manner. In particular, this is about contribution of labor to output.

Changes to economic systems at the turn of millennia have brought further increase in the fraction of production attributable to capital. This trend has been there at least since 1950s (Douglas 1976, p. 912). Technological change over the last 70 years, or so, decreased demand for labor, but empirical exercise shows significant differences within EU-27 in contribution of labor to real output.

In order to utilize this framework for projection, it must be fed with inputs. In this regard, one may refer to official demographic developments that are known for their high accuracy these days. In the current forecasting exercise, population statistics come from Eurostat. They should be considered as credible and reliable for this purpose. The other input, capital, has been separately projected in an $\operatorname{ARIMA}(5,1,3)$ model. The reason for employing such projection method is due to autoregressive nature of investment spending, except for rare periods of global financial crisis.

There may be a serious doubt when assuming quality and composition of European labor force remains unchanged over the projection horizon up to 2030. As argued by Młodkowski (2019), Europe has suffered from significant instability of population characteristics for more than one millennium. The situation may be different today, with no genocide, no plagues, no wars going on, but there are migration processes that introduce new characteristics into European labor force. However, their very impact on productivity remains uncertain. Further studies focused on immigrants' productivity may shed some more light on this issue and allow for a more informed assessment of real output. For simplicity, it is assumed that migrants from the Middle-East that arrived prior to 2018 will fully integrate with European societies, and start contributing to real output (and not consume more than produce) only after 2030 . This allows for keeping production function parameters at the same level, as estimated on 2004-2016 data. It should be noted that any forecasting for longer time horizons should consider implications of welcoming migrants to Europe.

Production function has been estimated with OLS for each of the EU-27 countries, plus the UK, for benchmarking. In addition, an aggregate EU-wide production function has been obtained to generate EU-27 joint forecast.

Data sources

Eurostat remains the most useful source of historic time series, and projections for EU-27. Estimation of production function parameters utilized real GDP and population data retrieved from Eurostat on-line database. Gross investment spending, as a proxy for capital, came from the on-line International Financial Statistics database, by the IMF.

Then, feeding production function for the purpose of projections until 2030 utilized two different solutions. Projection of gross capital formation was conducted in a simple autoregressive model of ARIMA class. Another variable, the population by country, was, again, provided by Eurostat for the period up to 2030 .

Projection of Real Growth in the EU
Presentation of real output projection for EU-27 is organized as follows. Countries are divided into three groups, using criterion of the real GDP per capita, in the projection period. Figure, from one to three, contain cases in decreasing order, from the richest to the poorest, with one exception of Luxembourg, due to significant difference of this one small economy. Luxembourg is reported as the last one in a figure with the poorest countries. 
Charts with projections offer information about annual growth rate in a form of bars (right-hand axis), and the level of the real GDP per capita in a form of a line (left-hand axis). Every figure, from 1 to 3, contains 9 EU countries organized in the descending order, from the highest GDP (per capita) to the lowest, in each of the three groups: high, middle, low. The first chart in each figure offers additional information about closing the gap between the richest country in a particular group, and the poorest EU country. Dotted line represents projected real GDP per capita for Bulgaria.

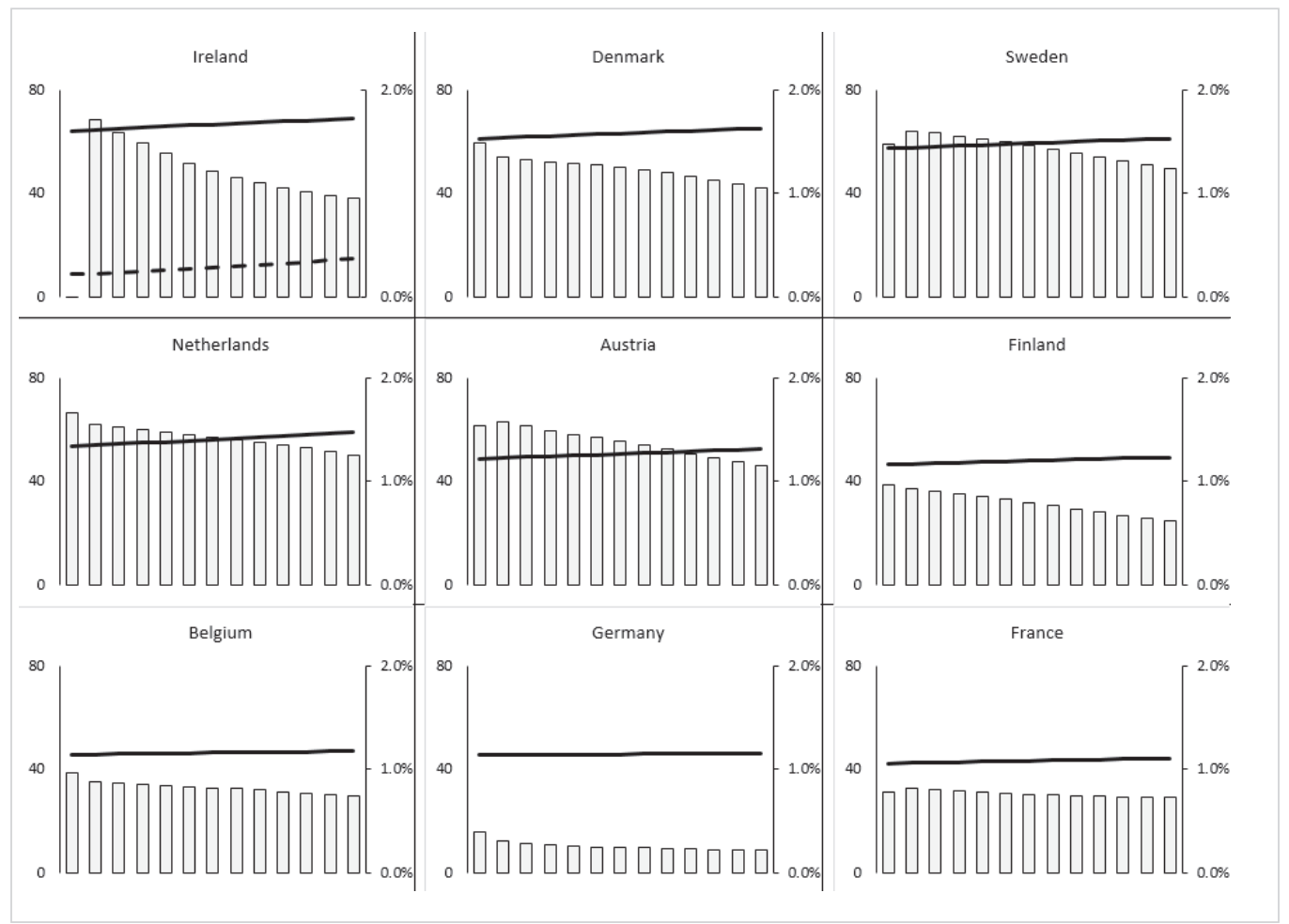

Figure 2 presents the richest EU countries: Ireland, Denmark, Sweden, Netherlands, Austria, Finland, Belgium, Germany, and France. The range of the projected real GDP growth rates is within 0\%-2\% bracket. The lowest growth rates for the whole period are projected for Germany. In spite relatively high growth rates for Ireland, this country may experience the sharpest decline in growth dynamics in this group. Slight decline in growth rate is expected also for Denmark, Netherlands, Austria, and Finland. Other countries in this group shall keep growing at a stable, but low (below 1\%) rate (i.e. Belgium, Germany, and France). Closing the gap between Ireland, and the poorest EU country seems to be very slow in the forecast horizon.

Figure 3 offers a mix of New Member States and few bigger EU members. One can find substantial diversity here, as projected growth rates for Italy, Spain, Greece, Cyprus, and Portugal are almost at zero. In the same time, Malta and Lithuania are expected to grow at 2\%-3\% annually. In case of the Czech Republic, and Slovenia, a sharp decline in growth rate is expected, bringing them in the latter periods to situation projected for all other countries in this group. Is this a manifestation of a middle-income trap? Due to almost no growth in Italy, the gap between this country and Bulgaria seem to substantially narrow.

Figure 4 delivers mostly positive prospects for all countries included in this group, except for Slovak Republic. Not only dynamic real GDP growth is going to disappear in Slovakia, but there is a decline expected, in the latter period. It will effectively narrow the gap in the real GDP per capita even more. Countries like Latvia and Romania are projected to grow at a stable $2 \%$ rate until
Figure 2

Growth projection for nine richest $\mathrm{EU}$ countries 2018-2030. Line: GDP per capita left scale in thousands of USD. Bar chart: real GDP growth rate in $\%$, right scale. Dotted line (Ireland): GDP per capita in the poorest EU country (Author, based on projection exercise). 
Figure 3

Growth projection for next nine EU countries 2018-2030. Line: GDP per capita left scale in thousands of USD. Bar chart: real GDP growth rate in $\%$, right scale. Dotted line (Italy): GDP per capita in the poorest EU country (Author, based on projection exercise).
Figure 4

Growth projection for next nine EU countries 2018-

2030. Line: GDP per capita left scale in thousands of USD. Bar chart: real GDP growth rate in \%, right scale. Dotted line (Slovakia): GDP per capita in the poorest EU country (Author, based on projection exercise).
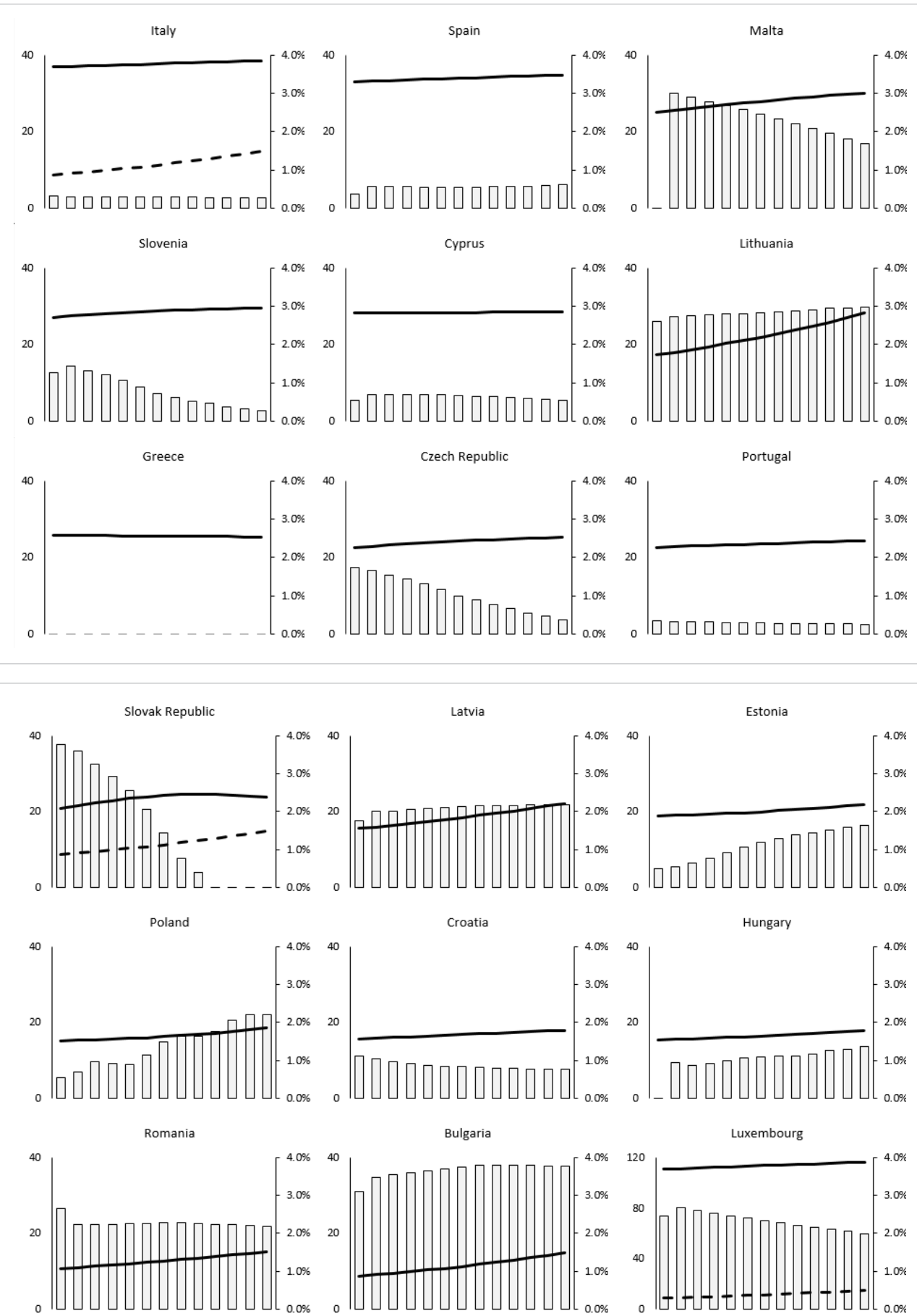

2030, improving standards of living significantly. Poland, and Estonia are going to systematically increase their respective real GDP growth rates, departing from 1\%, and arriving at $2 \%$ per annum in the latter periods. Bulgaria, as the poorest country in the EU seem to catch up effectively with the projected (almost) 4\% real growth in the next 12 years. Croatia and Hungary shall grow steadily, without any sharp developments, at 1\% per annum, until 2030.

Luxembourg, as an outlier, is not really suitable for comparisons with other EU members that operate totally different industrial organizations, and few more sectors of the national economy. 
Enough to say, Luxembourg is expected to maintain its real GDP growth rate at about 2\% per annum within the projection period. The reasons for this very special economy to expand are, however, different from other European countries. Most recent initiatives aimed at reducing tax avoidance and curbing abuses reported by Panama Papers may have a strong negative impact on economic growth of 'real' output in Luxembourg.

Projections of economic growth are a gentle topic for researchers and policymakers worldwide. Media focus on macroeconomimc prospects issuing variety of interpretations and explain possible consequences at national, regional, and global level. Governments and other institutions provide these forecasts of the real GDP using a wide range of methods, but none of them is really superior to others. In the current econometric exercise, a very simple framework has been utilized. Transformation of labor and capital, as a form of presenting production dates back to Marx and the very first political economy debates. The focus on these two growth factors in the current situation in the European Union is not a coincidence. Instability of working population in Europe prevailed over past centuries. The wave of migrants from the Middle East this seems to be a continuation in this tradition.

Real GDP projections for EU-27 for the next 11 years generated by country-level production function revealed few interesting features and probable changes to the current situation. First, it will become relatively difficult for Greece to overcome problems that resulted from years of negligence and avoidance of reforms, as this country may continue stagnation similar to that in Japan after 1991. Second, after many years of prosperous operations and amazing macroeconomic performance, this will be Ireland that depletes its resources and continues growth at a pace typical for other developed economies in Europe. Then, the third observation is about New Member States, which continue the catch up process, avoiding successfully the so-called "middle-income trap". In case of the EU countries with, currently, the lowest real GDP per capita, narrowing the income gap is expected over the projection horizon. Among these countries, Slovakia seems to be facing serious negative effects of labor force migration to richer EU Member States.

The results of the empirical investigation presented above allow for common EU policy to respond to the issue of distributing immigrants form the Middle East in two complementary ways. First, for the purpose of expanding the real GDP, immigrants could be allocated to those economies that are characterized with the negative parameter $\alpha$ (bottom of Table A1), which indicates net negative influence of EU integration on labor force, reflected in $\alpha$ parameter. The complementary policy in regard to immigrant allocation among EU countries could be based on the projected growth rate. According to this complementary idea, countries with the lowest, projected growth rates should receive the majority of immigrants. This way, national economic systems expected to experience the lowest, or declining, growth rates would receive an additional labor force. It has a potential of making the forecast presented above invalid. Expanding the labor force in expected to perform poorly economies, may generate real growth of output, motivated by additional domestic demand, and abundance of otherwise scarce resource. This group would include Slovakia and Greece.

Limitations of the current research resulted from inconsistent time series that were used for estimations of structural parameters. Many of the European countries included in the empirical exercise underwent significant systemic changes, and experienced substantial demographic transformations. An effort was made to cope with disturbances induced by socio-economic changes that modified the underlying production process, defined by a simple production function with labor and capital. Further research has few ways to follow. First, available time series may be used to estimate a different model for domestic output and presented projections may be verified. Second, the simple production function framework may be feed by updated, and adjusted, time series for labor and capital developments in the EU to provide updated forecasts. Third, structural parameters ( $\alpha$ and $\beta$ ) may be studied for their stability, and respective interpretation at country-level. Curious investigators may well follow still few other routes. 
References
Ackerknecht, E H. (1965). History and Geography of the Most Important Diseases. New York: Hafner Publishers, 1965.

Brecke, P. (2009). Violent Conflicts 1400 A.D. to the Present in Different Regions of the World, paper presented at the 1999 Meeting of the Peace Science Society (International) on October 8-10, 1999 in Ann Arbor, Michigan.

Brecke, P. (2012), Conflict Catalog, Retrived February 20th 2018, from http://www.cgeh.nl/sites/default/ files/Conflict\%20Catalog\%2018\%20vars.xls

Bywaters D. and Młodkowski P. (2012). The Role of Transactions Costs in Economic Growth, International Journal of Economic Policy Studies, Vol. 7, 2012, pp. 53 - 66. (http://www.jepa-hq.com/ijeps/content/2012/articles/Bywaters_Mlodlowski_IJEPS12. pdf ) https://doi.org/10.1007/BF03405737

Calic, M.-J. (2012). Ethnic Cleansing and War Crimes, 1991-1995. In Ch. W., Ingrao, \& T. A., Emmert, (Ed.), Confronting the Yugoslav Controversies: A Scholars' Initiative. West Lafayette, IN: Purdue University Press, 139-140.

Daugeliene R. \& Młodkowski P. (2014). Pattern of Financial Flows within the European Union: First Insights about Creditor-Debtor Country Relationship, European Integration Studies: Research and Topicalities, No 8, 2014, pp. 48-55 [DOI: http:// dx.doi.org/10.5755/j01.eis.0.8.7014]. https://doi. org/10.5755/j01.eis.0.8.7014

Douglas, P. H. (1976). The Cobb-Douglas Production Function Once Again: Its History, Its Testing, and Some New Empirical Values, Journal of Political Economy, 84(5), 903-916. https://doi. org/10.1086/260489

Fusco, I. (2007). The causes of the epidemic. In: F. Angeli (Ed.), Plague, demography and taxation in the Kingdom of Naples of XVII century [in Italian]. Milan (Italy); Franco Angeli, p. 32.

Goldman, W. Z. (2011). Inventing the Enemy: Denunciation and Terror in Stalin's Russia. New York: Cambridge University Press, p. 217. https://doi. org/10.1017/CB09780511994906

Gregg, Ch. T. (1985). Plague: An Ancient Disease in the Twentieth Century. Albuquerque: University of New Mexico Press, 1985.

Hays, J. N. (2005). Epidemics and pandemics their impacts on human history. Santa Barbara, Calif.: ABC-CLIO, p. 103.
LeMay, M. C. (2016). Global Pandemic Threats: A Reference Handbook: A Reference Handbook, ABCCLIO, Santa Barbara California, Denver Colorado.

Młodkowski P. (2019). Population Instability and Economic Growth in the EU, Journal of Population Research and Policy Review, forthcoming.

Młodkowski P. (2019). Monetary Integration Challenges in Asia-Pacific Region, Comparative Culture, No 20, pp. 31-46.

Młodkowski P. (2018). Economic Growth in EMU before and after 1999, Nierówności Społeczne a Wzrost Gospodarczy, No 52, 2/2018, pp. 21-33. https:// doi.org/10.15584/nsawg.2018.2.2

Młodkowski P. \& Aigul T. (2012). Performance of Capital Markets in the EU and Turkey. A Cointegration Analysis, European Integration Studies: Research and Topicalities, No 6, 2012, pp. 160-167 [DOI: http://dx.doi.org/10.5755/j01.eis.0.6.1517] https:// doi.org/10.5755/j01.eis.0.6.1517

Niewyk, D. (2000). The Columbia Guide to the Holocaust. Columbia University Press.

Paneth, N., Vinten-Johansen, P., Brody, H., \& Rip, M. (1998). A rivalry of foulness: official and unofficial investigations of the London cholera epidemic of 1854. American Journal of Public Health, 88(10), 15451553. https://doi.org/10.2105/AJPH.88.10.1545

Patterson, K. D. (1993). Typhus and Its Control in Russia 1870-1940. Medical History, 37, 361-381. https://doi.org/10.1017/S0025727300058725

Porter, S. (2001). 17th Century: Plague. Gresham College. Retrived March 22nd 2018, from https://www.gresham. ac.uk/lectures-and-events/17th-century-plague

Rosefielde, S. (1983). Excess Mortality in the Soviet Union: A Reconsideration of the Demographic Consequences of Forced Industrialization, 19291949. Soviet Studies, 35(3), 385-409. https://doi. org/10.1080/09668138308411488

Ross, D. (editor). UK travel and heritage - Britain Express UK travel guide. The London Plague of 1665. Retrived February 22nd 2018, from http://www. britainexpress.com/History/plague.htm

UCLA School of Public Health. (2018). Asiatic Cholera Pandemic of 1846-63. Retrived February 22nd 2018, from http://www.ph.ucla.edu/epi/snow/pandemic 1846-63.html.

United States Holocaust Memorial Museum. (2010). Axis Invasion of Yugoslavia - Croatia. Holocaust Encyclopedia. Retrived 12 $2^{\text {th }}$ February 2018. 


\begin{tabular}{|c|c|c|c|c|c|}
\hline Country & $\alpha: P O P$ & Se POP & $\beta: C A P$ & se CAP & $\alpha+\beta$ \\
\hline Belgium & 0.85 & 0.36 & 0.24 & 0.05 & 1.09 \\
\hline Denmark & 1.3 & 0.4 & 0.24 & 0.02 & 1.54 \\
\hline France & 1.17 & 0.19 & 0.25 & 0.02 & 1.42 \\
\hline Germany & 0.2 & 0.61 & 0.31 & 0.05 & 0.51 \\
\hline Greece & 1.45 & 1.46 & 0.23 & 0.04 & 1.68 \\
\hline Ireland & 1.33 & 1.14 & 0.24 & 0.09 & 1.57 \\
\hline Italy & 0.04 & 0.38 & 0.27 & 0.03 & 0.31 \\
\hline Luxembourg & 1.04 & 0.4 & 0.2 & 0.07 & 1.24 \\
\hline Netherlands & 1.77 & 0.72 & 0.33 & 0.04 & 2.10 \\
\hline Portugal & 0.26 & 1 & 0.2 & 0.04 & 0.46 \\
\hline Spain & 1.2 & 0.24 & 0.3 & 0.03 & 1.50 \\
\hline United Kingdom & 1.16 & 0.43 & 0.21 & 0.04 & 1.37 \\
\hline Austria & 1.21 & 0.49 & 0.37 & 0.07 & 1.58 \\
\hline Finland & 1.33 & 1 & 0.36 & 0.05 & 1.69 \\
\hline Sweden & 1.23 & 0.26 & 0.3 & 0.02 & 1.53 \\
\hline Cyprus & 0.75 & 0.26 & 0.18 & 0.03 & 0.93 \\
\hline Czech Republic & 3.51 & 1.38 & 0.39 & 0.06 & 3.90 \\
\hline Slovak Republic & 20.36 & 10.35 & 0.27 & 0.08 & 20.63 \\
\hline Slovenia & 4.48 & 1.87 & 0.31 & 0.06 & 4.79 \\
\hline Malta & 2.8 & 0.64 & 0.04 & 0.05 & 2.84 \\
\hline Estonia & -5.83 & 1.81 & 0.28 & 0.03 & -5.55 \\
\hline Hungary & -5.85 & 2.34 & 0.25 & 0.07 & -5.60 \\
\hline Latvia & -1.46 & 0.87 & 0.28 & 0.05 & -1.18 \\
\hline Lithuania & -1.81 & 0.7 & 0.18 & 0.04 & -1.63 \\
\hline Poland & -5.98 & 9.38 & 0.23 & 0.09 & -5.75 \\
\hline Bulgaria & -3.92 & 0.78 & 0.17 & 0.04 & -3.75 \\
\hline Romania & -2.25 & 0.6 & 0.29 & 0.04 & -1.96 \\
\hline Croatia & -0.96 & 1.45 & 0.29 & 0.05 & -0.67 \\
\hline
\end{tabular}

\section{Appendix}

Table A1

Production function coefficients for EU 28 (including UK)

\section{PAWE $Ł$ MŁODKOWSKI}

\section{$\mathrm{PhD}$}

School of International Liberal Arts, Miyazaki International College

\section{Fields of interests}

Theory of economics, transactions costs in GE models

\section{Address}

1405 Kano-hei, Kiyotake-cho,

Miyazaki-shi, Miyazaki 889-1605 Japan

E-mail:pawel.mlodkowski@gmail.com
About the author 